\title{
Effect of Academic Supervision of School Heads and School Culture on Quality Teaching Teachers
}

\author{
Susanti ${ }^{1}$, Dessy Wardiah ${ }^{2}$, Bukman Lian ${ }^{3}$ \\ ${ }^{1}$ SMP Negeri 2 Pulau Rimau, \\ ${ }^{2,3}$ Universitas PGRI Palembang \\ $($ cc) $\mathbf{E Y}$
}

\begin{abstract}
Academic supervision carried out by the principal is part of the function and authority of the principal. It provides oversight of every academic activity that takes place at his school. School culture is the habit that has been mutually agreed upon by the school community to improve the quality of education. The quality of teaching becomes the standard in the learning process implemented by teachers in the classroom. This research was conducted with the aim to determine the effect of school's supervisors and school culture on the quality of teaching in SMP Negeri Pulau Rimau. The study was conducted through a quantitative descriptive approach. The results of the research states that there is a positive and significant influence of the principal's academic supervision variable on the teaching quality of teachers; there is a positive and significant influence of school culture variable on the teaching quality of teachers; and there is influence of the academic supervision of school principal and school culture on the teaching quality.
\end{abstract}

Keywords - Academic Supervision, School Culture, Teaching Quality.

\section{INTRODUCTION}

The important role of education is still felt by the community until now, especially in the context of improving the quality of human resources. The community believes that one of the most effective ways to optimize human resources is through education (Tobari et al, 2018; Andriani et al, 2018; Fitria et al, 2019; Kristiawan et al, 2019). Therefore, the quality of education is important to consider from time to time can be improved. Education is believed by the community able to create or develop one's competency as well as to optimize the values that apply in the community. Such beliefs make education as hope for people to improve their standard of living. In principle, the hopes of the community have been stated explicitly in the state constitution, especially in the 1945 Constitution of the Unitary State of the Republic of Indonesia. To implement these objectives, a law was specifically regulated regarding education, Law Number 20 of 2003 concerning the National Education System.
The law regulates in detail the National Education System especially in Article 3 concerning the purpose of education held nationally is to develop one's abilities and shape the character and national civilization has dignity to create intelligent national life, education is also carried out to optimize all the potential possessed by students so that they are able and willing to become a whole human being, by believing in God, the implication of the students will have a noble character, have physical and psychological health, have the ability or knowledge, competent and creative in solving all problems, able to be independent, which will eventually become a citizen who is responsible for all his actions despite being in a democratic system.

In reality, human resources in Indonesia indicate that the potential is still far from expectations (Wandasari et al, 2019). It was proven in 2015 that the achievement of grades and ranking held through the Program of International Students Assessment (PISA), Indonesia's position was ranked 62 in Science, 63 in Mathematics and ranked 64 in reading aspect, the ranking compared to 70 other countries. 
From these data, it is clearly a concern that Indonesia is ranked below even almost as a lock of the countries that follow the PISA. The same was expressed by Iswadi (2016) the results of the mapping conducted by Trends in International Mathematics and Science Studies (TIMSS) in 2015 in scientific literacy abilities of students in Indonesia ranked 45 out of 48 countries, and the Program for The International Student Assessment (PISA) in 2015 published by the Organization for Economic Cooperation and Development (OECD) also showed Indonesia's position ranked 61 out of the total participating countries, 69 countries in the field of scientific literacy, which is important information and worrying about the condition of scientific literacy.

According to Rizkita (2016) Indonesian students have low scientific literacy skills and are below the international average score and Central Connecticut State University publishes research on the level of reading interest titled "World's Most Literate Nations". The study involved 61 countries as a sample, and the astonishing results for Indonesian education, that the fact Indonesia was ranked second in the bottom of the order of 60 out of 61 countries. Only better than Botswana, and very far behind some neighboring countries that are members of ASEAN. Likewise, Thailand ranks 59, Malaysia ranks 53, and is far behind that of the allied countries Singapore which is quite in the 36 position.

The teaching profession in Indonesia is less attractive, and has not yet received social status as a professional. The education system in Indonesia does not yet have clear accountable goals and expectations for schools and teachers. Educational professionals in Indonesia, including teachers, do not yet have autonomy in achieving educational goals (Pearson, 2014). If viewed from Widodo's statement (2015) that the number of workers who have good quality education is only around $33.1 \%$, while around $66.9 \%$ are workers who have poor education levels. Therefore, as part of an assessment of the quality of human resources, Indonesia is still categorized as a country that has not been of good quality. Widodo (2015) further stated that the quality of education is still categorized as low because there are factors that cause it. Among these factors 1) the quality of physical facilities not optimal; 2) the quality of teachers who still do not have equal standards; 3 ) teacher welfare is still low; 4) student achievement is not optimal; 5) equal opportunity for education that has not yet occurred; 6) the relevance of education to needs is not in line; 7) the high cost of education. Educators are an important part of the education process that has a
The low quality of teaching by teachers is basically due to the suboptimal professional attitude possessed by educators. As explained earlier, that a professional educator must be able to carry out systematic education that is with clear learning plans, carry out learning as planned, and carry out an objective assessment or evaluation of the work done by students during the learning process (Irmayani et al, 2018; Apriana et al, 2019). If this has not been done by educators, it indicates that the educator does not yet have qualified competence and will have implications for poor performance. As research conducted by Srinalia (2015), that the low quality of a teacher is caused by several factors, including: 1) intelligence; 2) health; 3) talent; 4) motives; 5) abilities and interests; 6) skills and abilities; and 7) personality.

Academic supervision of school principals is an effort that can be done in order to optimize the quality of teaching, the presence of a leader in the education unit is expected to assist teachers in carrying out their duties in a professional manner and be able to overcome the problems that occur and the expected implication to the quality of education becomes better or improved (Maralih, 2014). The same thing also stated by Gaol (2017) to improve the quality of teaching of teachers requires the role of the principal who is very important to direct teachers in the management of learning.

One of the human resources involved in organizing education is the principal. According to Kristiawan (2017) school principals are the driving force, determining the direction of school policies that will determine how school and education goals are generally realized. While Darmawati (2015) school principals must have managerial skills so that they can direct and mobilize all available resources to achieve organizational goals, on achieving efficiency and effectiveness of learning so that it becomes a necessity that one of the principals' tasks is supervisors, supervising work carried out by educational staff (Khasanah et al, 2019; Salwa et al, 2019; Renata et al, 2018).

It is important for school principals to act and have the ability to supervise, because through supervisor's information it will be obtained accurately so that it can be used as a guide to carry out strategies in order to improve teacher professionalism by optimizing the competencies that must be possessed. Supervision can be used as a tool to coordinate and lead a number of teachers and staff, each of whom has their own responsibilities. Supervisors must maintain that each teacher can carry out their duties properly in cooperative work situations. Kompri (2015) states that 
supervision is an evaluation, conducted by a school principal in order to obtain accurate information about the competencies possessed by educators. From this information, the school principal can determine the guidance policy according to the needs, so that the expected results are indeed in accordance with the objectives of the training to improve the competence of educators. From supervision it can also be known the needs of an educator regarding competencies that need to be improved.

Supervision activities carried out by some supervisors at this time still follow the old paradigm that is only oriented to the aspects of supervision (control) and the main object of supervision is carried out only on administrative activities, so that the atmosphere of partnership between teachers and supervisors is less created and even in a way Psychologically an educator has a moral burden because he feels as a person who is judged not as a colleague in implementing learning. The principle understanding of supervision activities is stated to be effective if at the time of supervision the condition or feeling is free from various pressures and should create an atmosphere of service delivery and fulfillment informal needs. Supervision of school principals applied so far is believed to be one of the factors inhibiting the progress of education which ultimately has an impact on the declining quality of teaching teachers.

Factors that hinder supervision a) a binding supervision schedule, because the schedule should be flexible to provide comfort if it is not so formal; b) the absence of a standard academic supervision format; c) insufficient understanding of the principal regarding the implementation of academic supervision that must be carried out; d) time constraints, as a leader the principal is also preoccupied with other tasks so that sometimes one of the tasks is forgotten or cannot be carried out optimally; e) the preoccupation of a school principal on official affairs which must be done and cannot be represented; and f) other activities that are not well scheduled so that the implementation of academic supervision sometimes does not work as it should (Wangid, 2015).

Masaong (2013), states that in supervision activities there are a number of deviations including 1) the lack of face-to-face meetings carried out by supervisors along with supervised teachers so that the results obtained tend to be done in an unreasonable manner; 2) administrative aspects are still the main thing to do at the time of supervision, even though many aspects must be supervised so that ignores other aspects such as professionalism of educators; 3) a supervisor comes from someone who is no longer directly related to the learning or education process carried out at school, so that the assessment conducted by the supervisor tends to persist in the old paradigm and has not followed the development of the ongoing learning process; 4) generally the system used is still top down or implemented from superiors to subordinates rather than being interactive; 5) less potential is available, such as other educators as supervisors in conducting supervision. Implementation of supervision can also be hampered due to factors internally from the supervisor itself, educators who are assigned and the environment around the implementation of supervision. Many things are also important to know about the obstacles that are often found in the implementation of supervision 1) the lack of spirit or enthusiasm found in an educator; 2) the authority of a leader who is deemed lacking; 3) weak creativity; 4) putting forward the formal system so that supervision is rigid; and 5) supervision implementation facilities that are still considered inadequate (Asmani, 2012)

A leader of the education unit, including the principal, should and in principle must have the ability or sufficient skills to carry out supervision, especially in the academic field, in order to carry out in accordance with the concept of academic supervision, therefore it will certainly affect the quality of teaching teachers. Not a few school principals conduct academic supervision by entering into classrooms where learning is taking place, as well as making unstructured observations of the organization of learning. Through such a short observation then expressed as a measurement in the context of academic supervision, this understanding is a mistake because academic supervision is not only done by visiting the teacher who is conducting learning in the classroom but starting an examination of the completeness of learning owned by the teacher. If the understanding of the supervision of education has been carried out correctly by the school principal, the expected implication is an increase in the quality of learning and an end in improving the overall quality of education.

Furthermore, other factors that influence teacher quality of teaching are school culture. Declared as school culture because it was carried out in a massive and structured way. The structured treatment occurs because it is the steps listed in the school's strategy to achieve school goals and the main objectives as stated in the school's vision. School culture was originally an understandable habit, which was carried out continuously by the school community. Until finally it became an activity that became the hallmark or character of the school. The existence of a school culture will usually have an impact on the love of the school, this is a good if interpreted as a strength and differentiator but can also lead 
to a negative thing if fanaticism towards the culture makes a difference and states that he is the best and most correct.

Pidarta (2000) states that school culture will be able to shape learning in schools to be more effective. School culture is a form of love for schools while maintaining the habits that are carried out in school. School culture is a positive thing to shape the school to have a certain character, which eventually the school will be known as the practice. In accordance with the previous description, that school culture is formed from the school's vision that is embedded in every element in the school environment. School culture will form a new style and new perspective for the community towards the intended school.

Habits that occur in schools or known as school culture, usually will have a certain reference. Sometimes it refers to a system that occurs in social life that has certain patterns or norms that are believed to be obeyed together. Finally, a culture will be a reference or reference in solving any problems that occur in the school environment. For this reason it is important to form a good school culture, so that the elements contained in the school will make goodness as a way to solve all problems in school. What is still held in the world of education today is culture that refers to the motto of tut wuri handayani, ing madya mangun karso, ing ngarso sung tulodo. Consciously or not, the motto has shaped the culture in the educational environment in Indonesia.

The quality of teaching that occurs in schools is inseparable from the culture that develops in the school. If the school culture requires active and creative and innovative learning, then every teacher and student will have a sense of responsibility to carry out such learning. Even without standard rules, the implementation of learning will be carried out well. This is thus stated as school culture has a strong influence on efforts to improve the quality of learning. There is no compulsion in conducting quality learning, if such culture has spread in every element of the school, it is believed that the quality of education will be better.

That is why, schools which is conducive to learning are needed. Because one of the factors that can provide and foster a school culture is a conducive school environment, not disturbed by the conditions contained around the school. If this can be realized, then the supervision process is not a complicated thing to do. Each element of the school is aware of its responsibilities, so it will work together in the administration of supervision because of the belief that supervision is not a judgment but rather a form of a process of quality improvement through evaluation of weaknesses in the administration of education. School culture often referred to culture in school, is formed by the habits or patterns that are carried out by every element in the school continuously so that it is held as the truth value in the school. That is why, the school culture is an activity that will continue to be maintained by the school community in daily learning. If a culture is going well, the learning held in class will run well and optimally

The smallest formal educational institution or education unit, the school, is a comfortable place to get education and knowledge. For this reason, it takes school culture that supports the process, if those needs can be created and fulfilled then the process of acquiring skills, knowledge, and competencies will be easier to obtain. If comfort is created from school culture, the learning process is easier to do. School culture which is able to create comfort for every element in the school, is important to be maintained and even improved. Thus, the educational objectives instructionally and nationally can really be optimally fulfilled. If the school element has felt the school as home, then the potential for character building in students and the process of transformation of values and knowledge will be more easily done by educators. It must be a joint agreement, that the school culture that supports the success of learning must be maintained by every element contained in the school.

When viewed from these aspects, it is believed that academic supervision is indeed needed to improve and optimize learning through evaluating the competencies held by educators in schools. As the aim of supervision is to provide encouragement to every educator to have competitiveness, to form a comfortable learning atmosphere, to create effective learning, so that educators will feel satisfaction with what they have done. If this can be realized, then the education system that is built will run as it should and national education goals can be achieved optimally.

Supervision carried out in schools, especially those carried out by principals on academic aspects, is a form of responsibility of a school principal in order to improve the quality of learning. Academic supervision must become a culture in schools, so that the implementation of supervision can continue to be carried out sustainably without any party feeling aggrieved or oppressed by the existence of academic supervision. Because everyone is aware that academic supervision is important in order to optimize the achievement of learning goals to obtain high quality learning. 
From the description above, the researcher feels it is important to make a deepening of these variables through research academic supervision of school principals and school culture on the quality of teaching. Academic supervision according to Sudjana (2011) is a procedure carried out by supervisors or principals in order to assist teachers in organizing education to achieve the goals set. According to Arikunto (2004) academic supervision is a supervision that focuses on the process of observing related to academic aspects, it can also be said to be a direct supervision of the scope of learning begins with the arranged learning planning, organizing learning in class and evaluation of learning organized by the teacher.

Based on the description of academic supervision, the researcher can conclude that academic supervision is a series of coaching activities and services provided by supervisors or principals in order to provide mentoring to teachers who organize learning. The results of academic supervision are as evaluation material to optimize the quality of learning so that the title as a professional teacher can be pinned on the teacher implementing the learning. In addition to supervision conducted in the academic, it was also identified that school culture has an impact on the quality of teaching teachers.

According to Zamroni (2003) that habits, values, norms, rituals, myths that are formed in the long journey of school, it applies continuously school culture. School culture is a characteristic that is owned by the school and tends to be valid in every generation so that the culture is timeless. From this description, the researcher concludes that what is meant by school culture is all values, norms and attitudes or behaviors of each member of the school group or community so as to form a uniquely agreed upon nature. Academic and cultural supervision of schools is assumed to have an impact on the quality of teaching of teachers.

In the context of education, the definition of quality refers to various aspects, input, process, outcome and impact. To understand the quality that is categorized in the input aspect, it can be seen in advance from its human resources, such as principals, educators, laboratory assistants found in schools, education staff and students. Furthermore, compliance with tools such as organizational structure, adequate regulations, as well as descriptions of the main tasks and functions of each element. The existence of vision, mission, goals and objectives is an important form of input quality to be analyzed first.

From the description above, the researcher concludes that the quality of teaching a teacher is a condition or good measure of the results of activities carried out by teachers, especially when providing knowledge to students with high levels of excellence such as having academic qualifications, competencies, physically and mentally healthy and having the ability to realize national education goals. To support the implementation of this research, there are several references that researchers use from the results of previous studies. Among them are research conducted by Amanda (2016); Ramadhan (2017); Rifaldi (2014); Sahin (2011); Suhayati (2013); Setiyati (2014); Ginting (2011); Murtiningsih (2019) and Wahyudi (2015).

\section{METHODS}

This research was conducted in Pulau Rimau Public Middle School. The schedule for conducting research was in September - October 2019. Based on the description of the main variables studied, the researcher used quantitative research methods to answer the research problem. Quantitative approach according to Arikunto (2010) is a research approach to prove a hypothesis that has been prepared, quantitative research is carried out because the data collected is in the form of numbers and analyzed by statistics, therefore the results of this study will also be in the form of numbers which are then interpreted in tables or guidelines other relevant.

This research is population research. Population research does not require a sample to generalize the results of the study because the study population is a research sample that describes the actual situation in the population without going through sampling techniques. For that the sample in this study amounted to 43 people. The research data were obtained through questionnaires, documentation and literature study. Regarding the questionnaire used in this study has been tested for validity and reliability, and the results state that the instrument is valid and reliable. Data analysis included classical assumption test analysis to determine the right test, while the classical assumptions tested were normality and heteroscedasticity. To test the hypothesis the " $t$ " test and the " $F$ " test are used which is done through simple and multiple regression analysis.

\section{Results AND Discussion}

Data obtained from the research carried out are described in the form of the following pictures. 


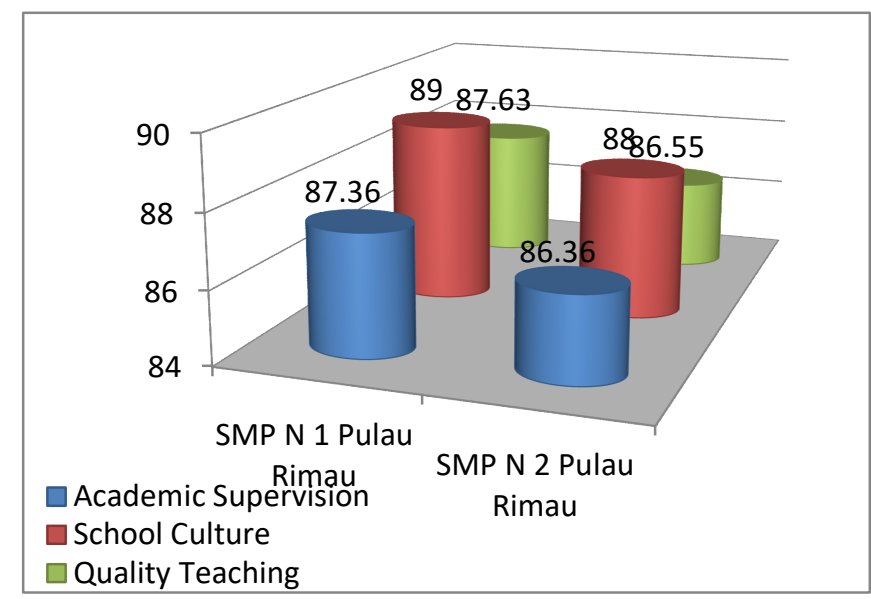

Figure 1. Average value of research variables

From the picture above, it appears that the average value obtained from the two schools that became the study sample has variations and differences. Although the difference is not so big, it's just that when you look at the comparison, SMP Negeri 1 Pulau Rimau is superior compared to SMP Negeri 2 Pulau Rimau. The data obtained are then tested for normality to determine the appropriate testing stage.

\subsubsection{Normality Test}

In this study the data normality test was carried out with the help of the SPSS program, the data normality was tested through the Kolmogorov-Smirnov (KS) test. The test results can be seen in the following table.

Table 1. Data Normality Test Results

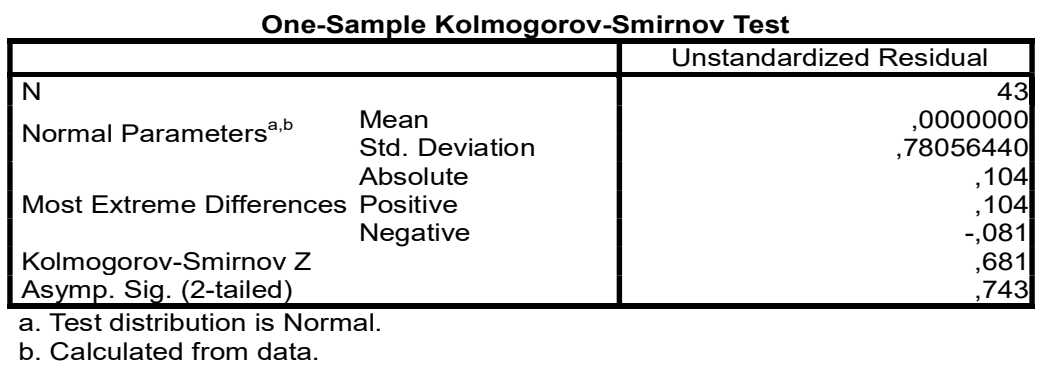

Based on the test results above, it is stated that the distribution of data in this study is normally distributed. This is evidenced by the significance value obtained at $0.743>$ 0.05 . Therefore, hypothesis testing can be done through parametric statistical analysis.

\subsubsection{Heteroscedasticity Test}

This test is a test conducted with the aim to assess whether there is an unequal variance in the value of each residual for all observations in the linear regression model. This test becomes important, because if heteroscedasticity assumptions are not met in the test, the resulting regression model is declared invalid to be used as a forecasting tool. This test has been carried out, and the results can be seen in the following figure. 
Scatterplot

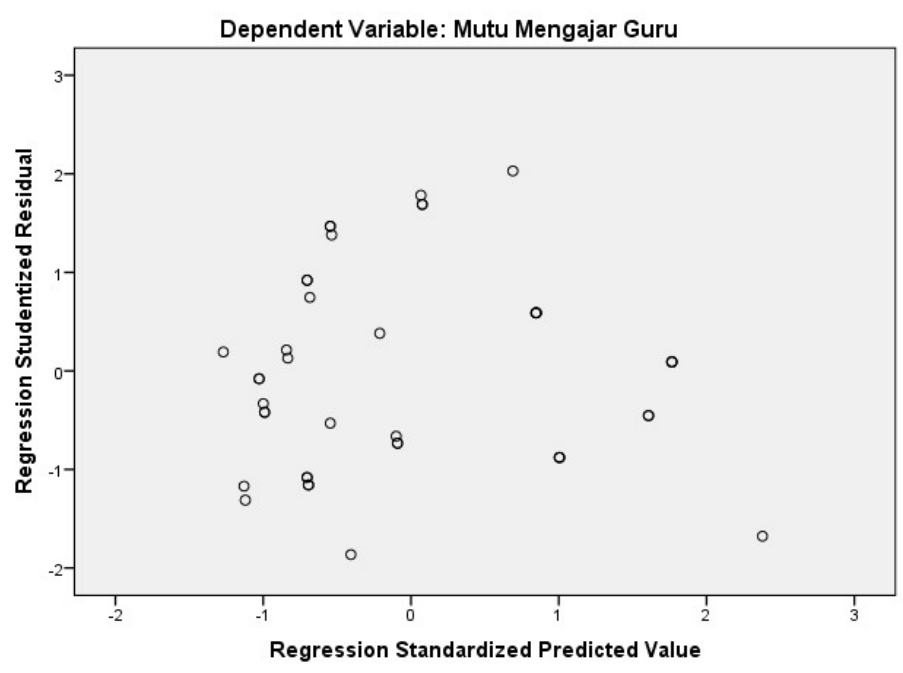

Figure 2. Heteroscedasticity Test Results

Based on the picture above which shows a scatterplot about the results of heteroscedasticity testing of research data. From the picture seen above, the researchers concluded that there were no symptoms of heteroscedasticity.

\subsubsection{Hypothesis Testing 1}

Hypothesis 1 in this study is testing for the first hypothesis, namely:
$\mathrm{H}_{1} \quad \mathrm{H}_{0} \quad$ It is suspected that there is no influence of : : $\quad$ academic supervision on the quality of teaching

$\mathrm{H}_{\mathrm{a}} \quad$ It is suspected that there is an influence of : academic supervision on the quality of teaching

Testing is done by using the SPSS program. The results obtained from testing the hypothesis 1 above are as follows:

Table 2. Hypothesis 1 Test Results "T-Test"

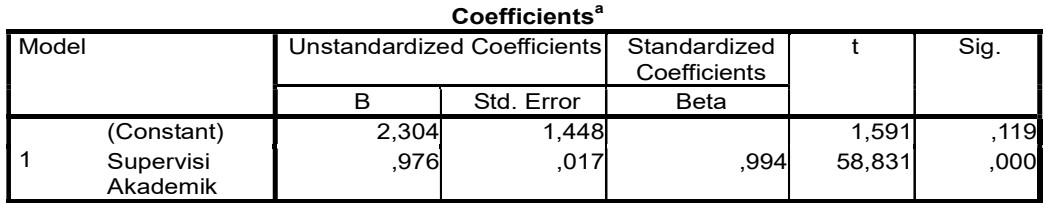

Based on the test results, it is known that the $\mathrm{t}$ value for the academic supervision variable is 58.831> t-table is 2.0195 which means that the alternative hypothesis (Ha) for testing hypothesis 1 is declared acceptable, therefore it is stated that there is a positive and significant influence on academic supervision the quality of teaching of teachers at
Pulau Rimau Public Middle School. To find out the magnitude of the correlation coefficient or the magnitude of the relationship and the coefficient of determinant or the magnitude of the influence of academic supervision on the quality of teaching teachers at Pulau Rimau Public Middle School, it can be seen in the following table.

Table 3. Correlational Coefficient and Determinant Coefficient Hypothesis 1 (H1)

\begin{tabular}{|l|c|r|r|r|}
\hline Model & R & R Square & Adjusted R Square & Std. Error of the Estimate \\
\hline 1 &, $994^{\mathrm{a}}$ &, 988 &, 988 &, 79606 \\
\hline
\end{tabular}

It is known that the $\mathrm{R}$ value is 0.994 which means the correlation coefficient or the magnitude of the relationship between academic supervision with the teaching quality of teachers is $99.4 \%$, included in the category of a very strong relationship. The $\mathrm{R}$ square value is known as 0.994 which means the coefficient of determinant or the amount of influence of academic supervision variables with the quality 
of teaching is 0.988 or the effect is $98.8 \%$ which means $\mathrm{fi}_{\mathrm{a}}$ : has a very high influence.

\subsubsection{Hypothesis Testing 2}

Hypothesis 2 testing in this study is intended to test the following hypotheses:

It is suspected that there is no influence of school culture on the quality of teaching
It is suspected that there is an influence of school culture on the quality of teaching

The results obtained from testing the above hypothesis, are as follows:

Table 4. Hypothesis 2 Test Results "T-Test"

\begin{tabular}{|c|c|c|c|c|c|c|}
\hline \multicolumn{7}{|c|}{ Coefficients $^{a}$} \\
\hline & \multirow{2}{*}{ Model } & \multicolumn{2}{|c|}{ Unstandardized Coefficients } & $\begin{array}{l}\text { Standardized } \\
\text { Coefficients }\end{array}$ & \multirow{2}{*}{$\mathrm{t}$} & \multirow{2}{*}{ Sig. } \\
\hline & & $B$ & Std. Error & Beta & & \\
\hline 1 & $\begin{array}{l}\text { (Constant) } \\
\text { Budaya Sekolah }\end{array}$ & $\begin{array}{r}-, 587 \\
, 991\end{array}$ & $\begin{array}{r}5,660 \\
, 064\end{array}$ & ,925 & $\begin{array}{r}-, 104 \\
15,549\end{array}$ & $\begin{array}{l}, 918 \\
, 000\end{array}$ \\
\hline
\end{tabular}

Known $\mathrm{t}$ value of 15.549 which is the calculated value for school culture variables. From this value, it is interpreted at the value of t-table is equal to 2.0185 which means tcount $>$ t-table; 15,549>2,0185 thus alternative hypotheses were accepted and stated that work culture had a positive and significant influence on the quality of teaching of teachers in Pulau Rimau State Junior High School. For the value of the correlation coefficient and the determinant coefficient of hypothesis testing above can be seen in the following table.

Table 5. Correlational Coefficient and Determinant Coefficient Hypothesis 2 (H2)

\begin{tabular}{|l|r|r|r|r|}
\hline Model & R & R Square & Adjusted R Square & Std. Error of the Estimate \\
\hline 1 &, $925^{\mathrm{a}}$ &, 855 &, 851 & 2,80149 \\
\hline
\end{tabular}

It is known that $\mathrm{R}$ is 0925 or it is defined that the magnitude of the correlation coefficient or the magnitude of the relationship between school culture and teacher teaching quality is $92.5 \%$. The magnitude of the relationship, included in the category very close. And in the $\mathrm{R}$ square column, seen a value of 0.855 or defined as a determinant coefficient or the magnitude of the influence of school culture variables with the teaching quality of teachers at $85.5 \%$ which is included in the very high category.

\subsubsection{Hypothesis Testing 3}

Hypothesis 3 testing is a hypothesis testing that is simultaneous or testing together. This third hypothesis reads:
$\mathrm{H}_{3}$ : $\quad \mathrm{H}_{0} \quad$ It is suspected that there is no influence of school academic and cultural supervision on the quality of teaching

$\mathrm{H}_{\mathrm{a}} \quad$ It is suspected that there is an influence of school academic and cultural supervision on the teaching quality

The results obtained from these tests can be seen in the following table.

Table 6. Hypothesis 3 Test Results "F-Test"

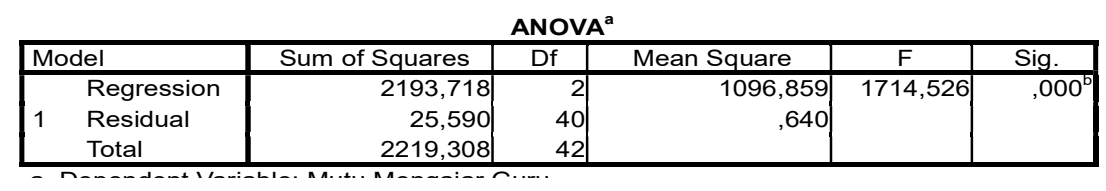

Based on the results of the analysis of simultaneous testing, it is clearly known that the alternative hypothesis (Ha) for hypothesis 3 (H3) is accepted. This can be seen from the Fcount value of 1714,526> FTabel of 1.91 which means that there is a positive and significant influence of school academic and cultural supervision on the teaching 
quality of teachers in Pulau Rimau State Junior High School. The magnitude of the influence of the two independent or independent variables on the dependent or dependent variable can be seen in the following table.

Table 7. Correlational Coefficient and Determinant Coefficient Hypothesis 3 (H3)

\begin{tabular}{|l|r|r|r|r|}
\hline Model & R & R Square & Adjusted R Square & Std. Error of the Estimate \\
\hline 1 &, $994^{\mathrm{a}}$ &, 988 &, 988 &, 79984 \\
\hline
\end{tabular}

Based on the results of data analysis using SPSS, it is concluded that the correlation coefficient or the magnitude of the relationship between the two independent variables (academic supervision and school culture) with the dependent variable (teacher teaching quality) of 0.994 or $99.4 \%$ which is categorized as a very strong relationship level. For the analysis of the determinant coefficient or the magnitude of the influence of the independent variables together on the dependent variable is 0.98 or $98.8 \%$ and is included in the category of very high influence.

As is known from the test results, the value of $t$ for the academic supervision variable is 58.831>t-table is 2.0195 which means that the alternative hypothesis $\left(\mathrm{H}_{\mathrm{a}}\right)$ for testing hypothesis 1 is declared acceptable, therefore it is stated that there is a positive and significant influence on academic supervision the quality of teaching of teachers at Pulau Rimau Public Middle School. The correlation coefficient or the magnitude of the relationship between academic supervision and teacher teaching quality is $99.4 \%$, included in the category of very strong relationships. The determinant coefficient or the magnitude of the influence of the academic supervision variable with the teaching quality of the teacher is 0.988 or the effect is $98.8 \%$ which means it has a very high influence.

The value of t-table for testing the second hypothesis is 2.0185 which means tcount $>$ t-table; 15,549>2,0185 thus alternative hypotheses were accepted and stated that work culture had a positive and significant influence on the quality of teaching of teachers in Pulau Rimau State Junior High School. The magnitude of the correlation coefficient or the magnitude of the relationship between school culture and teacher teaching quality is $92.5 \%$. The determinant coefficient or magnitude of the influence of school culture variables with the quality of teaching by teachers is $85.5 \%$ which is included in the very high category.

F-count value of $1714,526>$ F-Table of 1.91 which means there is a positive and significant influence of academic and cultural supervision of the school on the quality of teaching of teachers in Pulau Rimau State Junior High School simultaneously. The correlation coefficient or the magnitude of the relationship between the two independent variables (academic supervision and school culture) with the dependent variable (teacher teaching quality) of 0.994 or $99.4 \%$ which is categorized as a very strong relationship level. For the analysis of the determinant coefficient or the magnitude of the influence of the independent variables together on the dependent variable is 0.98 or $98.8 \%$ and is included in the category of very high influence.

The results of this study, especially in terms of the correlational coefficients and the determinant coefficients, were seen to have very high effects on the teaching quality of teachers. This is consistent with the theory of supervision, that a person needs to be monitored so that the work carried out can run optimally. Likewise with school culture, greatly influences the learning process undertaken by the teacher. That is why, in schools a quality culture must be developed that is comprehensive and integrated. This is important to consider to be done because it is through the school culture that a better quality culture will be formed. Therefore, this study reiterates the importance of the role of supervision in education and the importance of building a conducive school culture. For this to be a joint concern in the context of improving the quality of education.

The results of this study, support previous studies that have been conducted. As the research that has been described in relevant research, that the results of research conducted by previous researchers stated that academic supervision and school culture have a significant and positive influence on quality, although in previous studies stated the quality of education in general while in this study the quality of teaching teacher at school.

Therefore, the research clearly confirms that supervision conducted by the principal can help teachers improve the quality of teaching in the classroom. As the opinion expressed by several experts, that one of the factors that can affect the quality of teaching is supervision. So, if the supervision function is carried out optimally by the teacher, high quality learning will be obtained.

The research that has been done and the results that have been analyzed so that this report certainly has limitations. 
this is because there are many factors that influence including the limitations in the time of conducting research, limited funds to conduct research and the limited ability of researchers in conducting research. Nevertheless, it is understood that the shortcomings and limitations in this study can still be used as reference material and input to stakeholders in order to take appropriate and appropriate policies.

\section{CONCLUSION}

From the results of the research and discussion that have been described in the previous chapter, there are some important things that are the conclusions of the implementation of this research. That the variable academic supervision has a significant and positive influence on the quality of teaching of teachers in state junior high schools on Pulau Rimau. It is proven by the results of testing the hypothesis which states that the value of $t$-count $>t$-table as the interpretation process has been carried out, while the value of t-count 58.831> t-table is 2.0195; school culture has a significant and positive influence on the quality of teaching of teachers in state junior high schools on Pulau Rimau. It is proven by the results of testing the hypothesis which states that the value of $t$ is $15.549>t$-table 2.0185 as the interpretation process has been carried out; the academic and cultural supervision variables of the school together have a significant and positive influence on the quality of teaching of teachers in state junior high schools on Pulau Rimau, it evidenced by the results of testing the hypothesis which states that the value of F-Count is $1714.526>$ F-table of 1.91 .

\section{ACKNOWLEDGMENT}

We would like to express our special thanks and gratitude to Rector Universitas PGRI Palembang, Director of Graduate Program and the teachers of Primary School in Pulau Rimau who gave us the support to do this wonderful project. This project was funded independent. Secondly, we would also like to thank our friends in Management of Education who helped us a lot in finalizing this project within the limited time frame.

\section{REFERENCES}

[1] Amanda, M. O., Salam, R., \& Saggaf, S. (2016). The influence of the principal's supervision on the performance of teachers in SMK Negeri 1 Bungoro, Pangkep Regency. National Seminar "Social Sciences Education Shapes Nation Character in the Framework of Global Competitiveness", p. 149-154.
[2] Andriani, S., Kesumawati, N., \& Kristiawan, M. (2018). The Influence of the Transformational Leadership and Work Motivation on Teachers Performance. International Journal of Scientific \& Technology Research, 7(7).

[3] Apriana, D., Kristiawan, M., \& Wardiah, D. (2019). Headmaster's Competency In Preparing Vocational School Students For Entrepreneurship. International Journal of Scientific \& Technology Research, 8(8).

[4] Arikunto, S. (2004). Dasar-Dasar Supervisi Akademik [Fundamentals of Academic Supervision]. Jakarta: Rineka Cipta.

[5] Arikunto, S. (2010). Prosedur Penelitian Suatu Pendekatan Praktik [Research Procedure A Practical Approach]. Jakarta: Rineka Cipta.

[6] Asmani, J. M. (2012). Buku Panduan Internialiasi Pendidikan karakter di Sekolah [Handbook Internialization of Character Education in Schools]. Yogyakarta: Diva Press

[7] Darmawanti, R., Akhmad, M. \& Goris, G. (2015). The Effect of School Principal's Supervision on Teacher Performance in SMP Negeri 1 Parung, Parung District, Bogor Regency. Journal of Govenmation 1, (1).

[8] Fitria, H., Kristiawan, M., \& Rasyid, A. (2019). The Educational Character on Instruction. Opción, Año 35, Especial No.21 (2019): 964-979

[9] Ginting, B. (2011). Relationship between school organization culture and headmaster's leadership and the performance of Binjai City High School teachers. Tabularasa Journal Volume 8 Number 1, 61-72.

[10] Irmayani, H., Wardiah, D., \& Kristiawan, M. (2018). The Strategy of SD Pusri In Improving Educational Quality. International Journal of Scientific \& Technology Research, 7(7).

[11] Iswadi, H. (2016). A little from the 2015 PISA Results (online). Accessed from http://www.ubaya.ac.id/2014/content/articles_detail/23 0/Overview-of-thePISA-2015-results-that-have-justbeenReleased.html, dated May 30, 2019.

[12]Karsiyem \& Muhammad Nur Wangid. (2015). Academic Supervision Implementation In Improving Performance of Elementary School Teachers Group III Sentolo Kuloh Progo Journal of Management Education Accountability Volume 3, No 2, September 2015 Available online: http://journal.uny.ac.id/index.php/jamp.

[13] Khasanah, U., Kristiawan, M., \& Tobari. (2019). The Implementation of Principals' Academic Supervision In Improving Teachers' Professionalism in the State 
Primary Schools. International Journal of Scientific \& Technology Research, 8(8).

[14] Kompri. (2015). Manajemen Pendidikan 3 [Education Management 3]. Bandung: Alfabeta.

[15] Kristiawan, M., Nizarani., \& Syamsidar. (2019). Role of School on Forming Character of Z-Generation Through Entrepreneurial Skills. International Journal of Scientific \& Technology Research, 8(10).

[16] Kristiawan, M., Safitri, D., \& Lestari, R. (2017). Manajemen Pendidikan [Education Management].Yogyakarta: Deepublish.

[17] Kristiawan, M., Yuniarsih, Y., Fitria, H., \& Reflika, N. (2019). Supervisi Pendidikan [Educational
[Sula Supervision]. Bandung: Alfabeta.

[18] Maralih. (2014). The Role of Supervision in Improving the Quality of Education. Qathruna Journal Vol.1 No.1.

[19] Ma'ruf, T., Aswandi, \& Wahyudi. (2015). The influence of the principal's academic supervision and school culture on the quality of educational services.

[20] Masaong. (2013). Supervisi Pembelajaran dan Pengembangan Kapasitas Guru [Supervision of Learning and Teacher Capacity Development].

[21] Murtiningsih, M., Kristiawan, M., \& Lian, B. (2019). The Correlation Between Supervision of Headmaster and Interpersonal Communication With Work Ethos of the Teacher. European Journal of Education Studies.

[22] Pearson. (2014). The Learning Curve, Education and Skill For Life [The Learning Curve, Education and Skill for Life].

[23] Pidarta. (2000). Landasan Kependidikan [Educational foundation]. Jakarta: Rineka Cipta

[24]Ramadhan, A. (2017). The influence of the implementation of academic supervision of school supervisors and supervision of school principals on the performance of State Vocational School teachers in Majene Regency. EST Journal of Educational Science and Technology Volume 3 Number 2, 136-144.

[25] Renata, R., Wardiah, D., \& Kristiawan, M. (2018). The Influence of Headmaster's Supervision and Achievement Motivation on Effective Teachers. International Journal of Scientific \& Technology Research, 7(4).

[26] Rifaldi, M. A., \& Roesminingsih, E. (2014). The influence of the principal's supervision and teacher's work motivation on teacher job satisfaction in SMK $A D B$ Invest in Surabaya. Journal of Educational Management Inspiration Volume 4 Number 4, 122133.
[27] Rizkita, L. (2016). Analysis of Early Skills Literacy of High School Students (Thesis). Malang: Muhammadiyah University of Malang OECD. (2015).

[28]Sahin, S. (2011). The Relationship between Instructional Leadership Science and School Culture (Izmir Case).

[29] Salwa., Kristiawan, M., \& Lian, B. (2019). The Effect of Academic Qualification, Work Experience and Work Motivation towards Primary School Principal Performance. International Journal of Scientific \& Technology Research, 8(8).

[30] Setiyati, S. (2014). The influence of school principal leadership, work motivation and school culture on teacher performance. Journal of Technology and Vocational Education, 200-207.

[31] Srinalia. (2015). actors That Cause Poor Teacher Performance and Its Correlation Against Student Coaching. The Didactic Scientific Journal 2018.

[32] Sudjana, N. (2011). Supervisi Akademik Membina Profesional Guru Melalui Supervisi Klinis [Academic Supervision Fosters Teacher Professionals Through Clinical Supervision]. Jakarta: Binamita Publishing.

[33] Sugiyono. (2017). Metode Penelitian Kualitatif, Kuantitatif dan R\&D [Qualitative, Quantitative and $R \& D$ Research Methods]. Bandung: Alfabeta.

[34] Tobari., Kristiawan, M., \& Asvio, N. (2018). The Strategy of Headmaster on Upgrading Educational Quality In Asean Economic Community (AEC) Era. International Journal of Scientific \& Technology Research, 7(4).

[35] Undang-undang Number 20 of 2003 concerning the National Education System.

[36] Wandasari, Y., Kristiawan, M., \& Arafat, Y. (2019). Policy Evaluation of School's Literacy Movement on Improving Discipline of State High School Students. International Journal of Scientific \& Technology Research, 8(4).

[37] Widodo, H. (2015). A Portrait of Education in Indonesia and Its Readiness in Facing the Asian Economic Community (AEC) Cendikia Vol. 13 No.2

[38]Zamroni. (2003). School Based Management: Educational System Reform Tools. www. Diknas.go.id accessed on May 5, 2019.

[39]Zuchdi, D. (2011). Pendidikan Karakter Perspektif Teori dan Praktek [Character Education Perspective Theory and Practice]. Yogyakarta: UNY Press. 